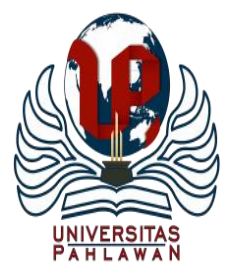

Edukatif : Jurnal Ilmu Pendidikan Volume 3 Nomor 3 Tahun 2021 Halm 890-899

EDUKATIF: JURNAL ILMU PENDIDIKAN

Research \& Learning in Education

https://edukatif.org/index.php/edukatif/index

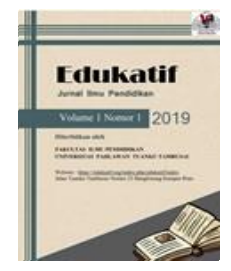

\title{
Potret Sikap Toleransi Mahasiswa Keguruan dalam Menyiapkan Generasi Rahmatan Lil Alamin
}

\author{
Akhwani $^{1 凶}$, Moh Wahyu Kurniawan ${ }^{2}$ \\ Universitas Nadhlatul Ulama Surabaya, Indonesia ${ }^{1}$ \\ Universitas Muhammadiyah Malang, Indonesia ${ }^{2}$ \\ E-mail : $\underline{\text { akhwani@unusa.ac.id }}^{1}$, wahyukurniawan@umm.ac.id ${ }^{2}$
}

\begin{abstract}
Abstrak
Mahasiswa keguruan memiliki posisi strategi dalam mempromosikan toleransi, karena pendidikan merupakan wadah untuk menumbuhkembangkan sikap toleransi. Penelitian bertujuan untuk menganalisis dan memberikan gambaran sikap toleransi mahsaiswa keguruan untuk menyiapkan generasi Rahmatan lil Alamin. Penelitian menggunakan pendekatan kuantitatif deskriptif dengan melibatkan mahasiswa Fakultas Keguruan dan Ilmu Pendidikan Universitas Nahdlatul Ulama Surabaya (Unusa) sebagai subjek penelitian. Hasil penelitian menunjukan terdapat empat indikator sikap toleransi, yaitu menghargai orang lain, menerima perbedaan, menghormati orang lain yang kondisinya berbeda, serta tidak memaksakan orang lain untuk sama dengan dirinya atau membiarkan membiarkan orang lain untuk bertindak sesuatu. Toleransi memiliki batasan, tidak semua tindakan dapat ditoleransi. Mahasiswa keguruan Unusa menunjukan sikap toleransi pada setiap unsurnya. 51\% mahasiswa keguruan Unusa sangat toleran, 39\% toleran dan 8\% cukup toleran dan sisanya hanya $2 \%$ yang kurang toleran. Toleransi perlu untuk dipupuk dan dikembangkan. Perbedaan selalu hadir di setiap kehidupan, namun perbedaan dapat menjadi indah seperti pelangi yang indah karena perbedaan warnanya.
\end{abstract}

Kata Kunci: Sikap, Toleransi, Mahasiswa, Keguruan.

\begin{abstract}
Teacher students have a strategic position in promoting tolerance, because education is a forum for cultivating tolerance. The research aims to analyze and provide an overview of the tolerance attitude of teacher students to prepare the generation of Rahmatan lil Alamin. The study used a descriptive quantitative approach involving students from the Teacher Training and Education Faculty of Nahdlatul Ulama University Surabaya (Unusa) as research subjects. The results showed that there were four indicators of tolerance, namely respecting others, accepting differences, respecting others with different conditions, and not forcing others to be the same as themselves or allowing others to act on something. Tolerance has limits, not all actions can be tolerated. Unusa teacher training students show tolerance in every element. $51 \%$ of Unusa's teacher students are very tolerant, $39 \%$ tolerant and $8 \%$ quite tolerant and the remaining $2 \%$ are less tolerant. Tolerance needs to be cultivated and developed. Differences are always present in every life, but differences can be beautiful like a beautiful rainbow because of the difference in color.
\end{abstract}

Keywords: Attitude, Tolerance, College Student, Teacher Training.

Copyright (c) 2021 Akhwani, Moh Wahyu Kurniawan

$\triangle$ Corresponding author

Email : akhwani@unusa.ac.id

DOI : https://doi.org/10.31004/edukatif.v3i3.455

ISSN 2656-8063 (Media Cetak)

ISSN 2656-8071 (Media Online)

Edukatif : Jurnal Ilmu Pendidikan Vol 3 No 3 Tahun 2021

p-ISSN 2656-8063 e-ISSN 2656-8071 
891 Potret Sikap Toleransi Mahasiswa Keguruan dalam Menyiapkan Generasi Rahmatan Lil Alamin - Akhwani, Moh Wahyu Kurniawan

DOI: https://doi.org/10.31004/edukatif.v3i3.455

\section{PENDAHULUAN}

Indonesia merupakan negara yang berbhinneka. Beragam agama, suku, adat, bahasa, menjadikan Indonesia sebagai negara yang majemuk. Indonesia memiliki 13.466 pulau dengan jumlah penduduk sekitar 258 juta jiwa, yang terdiri dari 207 suku bangsa yang terbentang dari Sabang sampai Merauke. Founding fathers sangat tepat memilih "Bhinneka Tunggal Ika" sebagai semboyan negara, karena penduduk Indonesia memang beragam. Pendiri bangsa menyadari betul bahwa penduduk Indonesia tidak berasal dari satu golongan saja. Cita-cita mulia persatuan di atas perbedaan harus diimplementasikan untuk menjaga keharmonisan kehidupan di tengah masyarakat yang heterogen.

Kebhinnekaan jika tidak disikapi dengan bijak dapat memunculkan konflik yang mengancam persatuan. Negara Kesatuan Republik Indonesia (NKRI) dapat terpecah jika warga negara di dalamnya tidak memiliki sikap toleransi (Ramadhaniar et al., 2020). Munculnya anggapan yang menilainya dirinya atau kelompoknya yang paling benar, unggul, ataupun paling baik diantara kelompok lain menjadi penyebab utama terjadinya perpecahan. Pada akhirnya sikap narsisme atau sikap yang merasa dirinya yang paling sempurna dibanding yang lain. Konflik di Indonesia akan terjadi jika kelompok yang memiliki sikap narsisme berinteraksi dalam masyarakat yang mejemuk. Konflik bernuansa SARA (suku, agama, ras dan antargolongan) menjadi tantangan bagi bangsa Indonesia. Nilai-nilai toleransi menjadi harga mati bagi warga negara Indonesia. Konflik antaretnis, kekerasan, umumnya terjadi karena rendahnya sikap toleransi (Schirmer et al., 2012). Perselisihan yang berlatarbelakang SARA harus dihindari karena Indonesia dibangun dari bangsa-bangsa yang berbeda. Toleransi menjadi kunci untuk menumbuh kembangkan rasa persatuan, kebersamaan, keharmonisan, dan kerukunan diantara perbedaan (P. Balint, 2016). Perbedaan sebenarnya dapat menjadi peluang dan modal kekayaan bagi Bangsa Indonesia. Dengan perbedaan yang dimiliki, Indonesia menjadi bangsa yang memiliki kekayaan budaya, adat, bahasa, serta tradisi. Kebhinnekaan merupakan ciri khas yang membedakan Indonesia dengan negara-negara lain. Indonesia akan menjadi negara besar jika masyarakatnya mampu menghargai dan menerima perbedaan sebagai anugerah dari tuhan yang wajib disyukuri. Bahkan stabilitas dan perdamaian dunia hanya dapat dibangun di atas toleransi dan menghargai perbedaan (Starkey \& Osler, 2006). Artinya toleransi adalah kunci untuk mencapai persatuan di atas perbedaan.

Hasil penelitian menunjukan intoleransi di Indonesia memiliki kecenderungan naik. Data yg dihimpun oleh Wahid Institude pada Januari 2020 menyebutkan bahwa sikap intoleransi di Indonesia meningkat 8\% dari 46\% menjadi 54\% (Mediaindonesia.com, 2020). Hasil tersebut senada dengan laporan Setara Institude pada September 2020. Hasil penelitian melaporkan bahwa pelanggaran kebebasan beragama atau berkeyakinan (KKB) terus terjadi, ekspresi intoleransi mengalami peningkatan intensitas (Setara-institute.org, 2020). Kedua hasil penelitian tersebut menjadi data yang perlu dicermati sekaligus sebagai bahan evaluasi dalam membangun keragaman di Indonesia. Data di atas memberikan indikasi adanya kesenjangan antara kondisi sikap toleransi di lapangan dengan kondisi ideal yang harusnya ada.

Nila-nilai toleransi perlu dipromosikan di semua lapisan masyarakat. Cara paling efektif untuk mencegah intoleransi dan permasalahan keragaman adalah dengan mempromosikan nilai-nilai toleransi melalui pendidikan (Lægaard, 2010; UNESCO, 1994, 1996). Sekolah harus mengajarkan nilai-nilai kebersamaan, persatuan, saling menghormati, menghargai dan memahami satu sama lain. Sikap toleransi tidak akan muncul secara tiba-tiba, perlu adanya upaya untuk menanamkan dan mengembangkannya sehingga menjadi sebuah karakter. Guru memiliki peran penting dalam mempromosikan nilai-nilai toleransi dalam lingkup pendidikan. Sebelum mempromosikan nilai-nilai toleransi maka guru harus meyakini dan memiliki nilai-nilai toleransi terlebih dulu. Guru-guru perlu dipersiapkan agar memiliki nilai toleransi sehingga pada saat mendidik dapat menanamkan nilai-nilai toleransi. Persiapan tersebut bisa dimulai dari sejak berada di bangku mahasiswa. Perlu dianalisis apakah mahasiswa keguruan sejatinya telah tertanam nilai-nilai toleransi atau justru belum memiliki. Boomerang akan terjadi apabila mahasiswa keguruan tidak memiliki sikap 
892 Potret Sikap Toleransi Mahasiswa Keguruan dalam Menyiapkan Generasi Rahmatan Lil Alamin - Akhwani, Moh Wahyu Kurniawan

DOI: https://doi.org/10.31004/edukatif.v3i3.455

toleransi, karena mereka akan mengajarkan kepada generasi masa depan. Guru menjadi juru penuntun untuk mempersiapkan generasi Rahmatan lil Alaimin.

Mahasiswa dianggap sebagai tunas-tunas yang nantinya akan menjadi pemimpin dan membawa arah negara (Amrin, 2021; Maulana, 2021). Mahasiswa dituntut untuk memiliki nilai-nilai toleransi dalam kehidupan berbangsa dan bernegara. Setinggi apapun pengetahuan yang dimiliki, sehebat apapun keterampilan yang dimiliki jika tidak diiringi dengan sikap yang baik maka tujuan pendidikan tidak akan terwujud. Sebagaimana yang tertuang dalam Undang-undang No. 20 Tahun 2003 pasal 3 bahwa tujuan pendidikan adalah mengembangkan potensi peserta didik agar memiliki akhlak mulia (Undang-undang 20, 2003). Artinya, sikap merupakan komponen yang tidak boleh ditinggalkan dalam ranah pendidikan. Sikap harus dijadikan pijakan dari pengetahuan dan keterampilan yang dimiliki.

Yewangoe memandang mahasiswa mampu tampil sebagai garda depan dalam mewujudkan toleransi dan kerukunan di masyarakat (Bahari, 2010). Mahasiswa merupakan bagian-bagian yang tidak terpisahkan dari masyarakat. Intoleran yang terjadi di masyarakat menjadi keprihatinan yang perlu dituntaskan. Sebagai insan cendekia, mahasiswa tentu dapat memilah persoalan secara objektif dan kritis. Keunggulan tersebutlah yang diharapkan mampu memberikan harapan persatuan di Indonesia. Sebagai calon guru, mahasiwa keguruan di Universitas Nahdlatul Ulama Surabaya (Unusa) harus memiliki kompetensi kewaganegaraan. Artinya mahasiwa selain memiliki pengetahuan dan keterampilan juga harus memiliki sikap toleransi (Akhwani, 2018). Terlebih lagi Unusa merupakan kampus dengan tagline menyiapkan generasi Rahmatan lil Alamin. Artinya mempersiapkan generasi yang kasih sayang, toleran, pemaaf dan persuasif (Mucharomah, 2017). Mahasiswa Keguruan memikul tugas mulia dalam rangka mencerdaskan anak bangsa serta membangun akhlak mulia. Guru merupakan role model bagi peserta didik (Kusumawardani et al., 2021). Peserta didik menjadikan guru sebagai teladan. Bisa dibayangkan jika guru tidak memiliki sikap yang baik maka ia akan dikucilkan, sekalipun ia memiliki pengetahuan yang mumpuni. Pepatah mengatakan "guru kencing berdiri, murid kencing berlari”. Guru memiliki peran penting untuk membentuk karakter peserta didik (Akhwani \& Nurizka, 2021). Tidak sampai di situ, sebelum guru mendidik karakter, guru harus memiliki sikap yang terpuji dahulu.

Penelitian untuk mengukur tingkat toleransi mahasiswa khususnya keguruan penting untuk dilakukan. Jangan sampai sebagai calon guru justru nilai-nilai toleransinya sangat rendah. Rendahnya sikap toleransi akan membahayakan bagi peserta didik. Fokus penelitian terkait toleransi pada level mahasiswa belum banyak yang mengkaji. Hasil penelitian dapat menjadi data yang menggambarkan sikap toleransi pada level mahasiswa. Oleh karena itu peneliti tertarik untuk melakukan penelitian tentang sikap toleransi mahasiwa FKIP Unusa. Keamanan Visi Unusa dalam mempersiapkan generasi yang toleran sangat sesuai dengan tantangan zaman. Hal ini bisa dijadikan sebagai referensi maupun evaluasi bagi mahasiwa, perguruan tinggi, pemangku kepentingan, akademisi dan lainnya. Lebih dari itu juga dapat dijadikan pijakan bagi peneliti berikutnya tentang sikap toleransi.

\section{METODE}

Penelitian dilakukan dengan menggunakan pendekatan kuantitatif deskriptif. Penelitian dilakukan di Universitas Nahdlatul Ulama Surabaya (Unusa). Penelitian memberikan gambaran sikap toleransi mahasiswa keguruan atau Fakultas Keguruan dan Ilmu Pendidikan (FKIP) Unusa yang terdiri dari Mahasiswa Pendidikan Guru Sekolah Dasar (PGSD), Pendidikan Guru Pendidikan Anak Usia Dini (PG PAUD) dan Pendidikan Bahasa Inggris (PBI). Populasi penelitian adalah seluruh mahasiswa FKIP yang berjumlah 655. Penentuan sampel penelitian menggunakan rumus Slovin (Supriyanto \& Iswandari, 2017) sehingga diperoleh jumlah sampel 248. Angka tersebut merupakan angka minimal. Responden yang terlibat sebanyak 276 mahasiswa, artinya lebih tinggi dibandingkan jumlah sampel yang dibutuhkan. Adapun tingkat kepercayaan 95\% dan 
893 Potret Sikap Toleransi Mahasiswa Keguruan dalam Menyiapkan Generasi Rahmatan Lil Alamin - Akhwani, Moh Wahyu Kurniawan

DOI: https://doi.org/10.31004/edukatif.v3i3.455

kesalahan 5\%. Teknik pengumpulan data menggunakan angket skala likert. Penelitian menggunakan jenis survey dengan instrumen yang sudah diuji coba, diuji validitas dan reliabilitasnya. Instrumen diberikan secara online dan direkap dengan bantuan Lime Survey. Terdapat 40 butir instrumen yang sudah valid dan reliabel. Insrumen menggunakan skala likert. Data dianalisis dan dioleh menggunakan bantuan Lime Survey dan descriptive SPSS. Hasil analisis data disajikan secara deskriptif kemudian digunakan sebagai rujukan untuk membuat kesimpulan.

\section{HASIL DAN PEMBAHASAN}

Toleransi merupakan kunci terwujudnya keharmonisan dalam kehidupan bernegara. Orang yang toleran secara tidak langsung telah menyokong terwujudnya persatuan di lingkungannya. Tanpa ada toleransi maka konflik dan perselisihan dapat mengancam persatuan. Toleransi menjadi perekat di antara perbedaanperbedaan yang ada di masyarakat. Oleh karena itu sikap toleransi mutlak dimiliki oleh setiap individu, terlebih lagi bagi guru yang mengembangkan tugas pendidikan karakter bagi generasi masa depan.

\section{Sikap Toleransi dalam Bingkai Kebhinnekaan}

Kebhinnekaan di Indonesia mutlak membutuhkan sikap toleransi. Toleransi merupakan respon dari keragaman dan perbedaan (Besch \& Lee, 2017; Lee \& Besch, 2018). Perselisihan antar kelompok, antar agama atau antar budaya akan muncul ketika tidak didasari oleh nilai-nilai toleransi. Keberagaman dapat menjadikan Indonesia menjadi negara yang indah, kokoh, dan kuat. Keragaman juga dapat menjadi ancaman yang membawa petaka dan kehancuran. Semua tergantung pada warga negaranya, mampu atau tidak menciptakan keindahan dari keragaman tersebut.

Toleransi dapat dimaknai sebagai tenggang rasa, mengakomodasi sudut pandang yang berbeda, menyadari bahwa setiap orang memiliki pandangan yang berbeda serta menjunjung tinggi kebersamaan (Kemdiknas, 2020). Ada tiga poin yang harus dipenuhi dalam toleransi. Poin tersebut adalah rasa hormat, menerima, mengapresiasi terhadap keragaman dan ekspersi manusia. Toleransi tidak cukup dengan menghormati perbedaan, tetapi juga harus disertai dengan sikap menerima adanya perbedaan yang kemudian diekspresikan melalui sebuah tindakan.

Orang yang memiliki sikap toleran memiliki dua pandangan. Pertama, tidak membuat orang melakukan sesuatu yang tidak mereka inginkan. Kedua, tidak mencegah orang lain untuk melakukan sesuatu yang diinginkan (Dasli, 2016; Jones, 2010). Orang yang toleran adalah orang yang mampu menekan apa yang tidak disukai, namun memilih untuk tidak melakukannya. Orang yang toleran menghargai dan menyadari adanya sesuatu yang tidak bisa dipaksakan, sehingga memilih untuk membiarkan.

Tidak semua hal dapat ditoleransi. Ada beberapa hal yang tidak boleh ditoleransi. Toleransi harus memiliki batasan (Dasli, 2016). Perbuatan yang menyimpang dari moral tidak dapat ditoleransi. Misalnya tindakan pembunuhan, pemerkosaan, perampokan tidak boleh ditoleransi. Hal tersebut tidak sesuai dengan norma-norma yang melekat di dalam masyarakat. Semua orang tentu tidak akan setuju jika tindakan yang tidak bermoral ditoleransi. Hal ini berbeda dengan sudut pandang atau pendapat seseorang tentang suatu hal yang tidak menyangkut prinsip moral. Dengan kata lain, Artinya toleransi terjadi karena terdapat perbedaan dan menghormati perbedaan atau prinsip orang lain tanpa mengorbankan norma-norma yang telah dipegang.

Terdapat empat komponen atau unsur-unsur yang ada dalam sikap toleransi. Komponen ini dikembangkan peneliti dari kajian teori dan pendapat (Bahari, 2010; P. Balint, 2016; P. A. Balint, 2010; Bukhori, 2021; Ruyter \& Miedema, 2011). Empat unsur tersebut adalah Menerima, menghargai, menghormati dan membiarkan. 
Tabel 1. Indikator Sikap Toleransi

\begin{tabular}{|c|c|}
\hline Indikator & Penjabaran \\
\hline \multirow[t]{3}{*}{ 1. Menerima perbedaan } & $\begin{array}{l}\text { a. Merasa nyaman bersama dengan siapa saja meskipun } \\
\text { berbeda }\end{array}$ \\
\hline & $\begin{array}{l}\text { b. Memahami bahwa sudut pandang setiap orang tidak } \\
\text { bisa disamakan }\end{array}$ \\
\hline & c. Menolak perbedaan dengan baik \\
\hline \multirow[t]{3}{*}{ 2. Menghargai orang lain } & $\begin{array}{l}\text { a. Memberi kebebasan untuk bertindak sesuai dengan } \\
\text { prinsipnya }\end{array}$ \\
\hline & $\begin{array}{l}\text { b. Tidak membeda-bedakan atau memberikan perlakukan } \\
\text { yang sama }\end{array}$ \\
\hline & c. Menghargai orang lain meskipun berbeda \\
\hline \multirow{3}{*}{$\begin{array}{l}\text { 3. } \\
\text { kenghormati } \\
\text { keyanan orang lain }\end{array}$} & a. Tidak meremehkan orang lain \\
\hline & b. Menghormati orang lain, tanpa memandang identitas \\
\hline & c. Tidak merasa paling benar \\
\hline \multirow{3}{*}{$\begin{array}{l}\text { 4. Membiarkan atau } \\
\text { Tidak memaksakan } \\
\text { keinginan }\end{array}$} & a. Membiarkan seseorang berbeda dengan dirinya \\
\hline & b. Tidak memaksakan kepada orang lain \\
\hline & c. Lapang dada dengan perbedaan. \\
\hline
\end{tabular}

\section{Urgensi Sikap Toleransi Bagi Guru}

Sikap toleransi menjadi kajian penting yang tidak boleh ditinggalkan. Sikap toleransi merupakan sebuah kondisi yang harus diterapkan di negara multikuktural seperti Indonesia. Indonesia merupakan negara yang syarat akan keragaman. Akan sangat berbahaya jika tidak disertai dengan sikap saling menghormati, menghargai, dan memberiarkan orang lain bersikap sesuai dengan keyakinannya.

Mahasiswa Keguruan, khususnya FKIP Unusa sebagai calon guru memiliki tugas berat untuk mengemban misi undang-undang dalam rangka mencerdaskan kehidupan bangsa. Tidak cuma itu, mahasiswa FKIP Unusa sebagai calon guru juga memiliki tanggung jawab penuh dalam rangka mengemban pendidikan karakter anak. Pendidikan tidak hanya terbatas pada pengetahuan atau keterampilan saja (Akhwani, 2019). Pendidikan adalah kesatuan dari pengetahuan, keterampilan dan sikap. Tidak boleh ada satupun intrumen yang ditinggalkan dalam pendidikan. Unusa sebagai kampus yang memiliki Visi Rahmatan lil Alamin tentu sudah merencanakan betul karakter atau kepribadian lulusannya. Mahasiswa ditanamkan nilia-nilai Tawassuth (moderat), Tawazun (seimbang), dan Tasamuh (toleransi) dalam melaksanakan setiap aktivitas yang berkonstribusi untuk mencapai Generasi Rahmatan lil'alamin. Terlebih mahasiswa FKIP yang pada nantinya diarahkan menjadi calon-calon guru yang mendidik generasi masa depan. Tentu akan sangat berbahaya sekali apabila calon guru ternyata tidak memiliki nilai-nilai sebagaimana amanah undang-undang. Guru harus memiliki sifat dan kepribadian yang baik.

Guru merupakan figur yang menjadi panutan siswanya. Guru tidak hanya mengajarkan tentang pengetahuan semata, tapi lebih dari itu menjadi teladan bagi siswa atau peserta didiknya (Suriadi et al., 2021). Oleh karena itu Undang-undang Nomor 14 Tahun 2005 pasal 10 ayat 1 menyebutkan bahwa guru harus memiliki kompetensi pedagogi, kompetensi kepribadian, kompetens sosial dan kompetensi profesional. Empat hal yang harus dimiliki guru (Indonesia, 2005). Sikap toleransi merupakan bagian yang tidak boleh ditinggalkan dalam mengajarkan sikap anak. Bagaimana mungkin peserta didik menjadi pribadi yang memiliki sikap baik sementara gurunya belum memiliki sikap yang baik pula. Guru merupakan sosok yang diharapkan menjadi role model bagi peserta didik. Jangan sampai guru justru menebar ujaran kebecian terhadap orang lain. Guru yang toleran cenderung akan mengarahkan peserta didik untuk turut toleran. Anak akan cenderung mengikuti atau meniru orang dewasa (immitation).

Dalam tesisnya Yewangoe menyebutkan bahwa mahasiswa mampu menjadi garda terdepan dalam mengembangkan sikap toleransi (Bahari, 2010). Pernyataan tersebut seolah menunjukan bahwa toleransi dapat 
digerakkan siapapun termasuk mahasiswa. Bahkan mahasiwa memiliki peran utama sebagai menjadi garda terdepan. Apalagi sebagai seorang calon guru yang nantinya menegmban misi untuk mengemangkan akhlak mulia sebagaimana yang tertuang dalam Undang-undang Sistem Pendidikan Nasional.

\section{Sikap Toleransi Mahasiswa Keguruan}

Sebagai pelukis wajah masa depan bangsa Indonesia, guru mutlak memiliki sikap toleransi. Tanpa adanya toleransi akan sulit terwujud persatuan, karena toleransi adalah kunci persatuan (Schirmer et al., 2012). Toleransi perlu dipupuk dan dikembangkan. Sikap toleransi yang baik diharapkan dapat memberikan pengaruh yang positif bagi orang disekitarnya, karena pada dasarnya manusia akan berbuat baik jika diberi perlakuan yang baik pula. Mahasiswa keguruan dengan sikap toleransi yang baik diharapkan mampu menularkan kepada peserta didik kelak ketika menjadi guru. Berdasarkan data hasil penelitian menunjukan bukti bahwa mahasiwa FKIP Unusa memiliki kecenderungan sikap toleransi dan jauh dari kata intoleran. Hal ini bisa dilihat dari empat indikator sikap toleransi memiliki prosesntasenya tinggi dibandingkan dengan sikap tidak toleran. Artinya sikap menghargai, menerima, menghormati perbedaaan dan membiarkan orang sesuai keyakinan mewakili kepribadian mahasiswa FKIP Unusa. Rangkuman ini dapat dijadikan sebagai pembanding, pada bagian mana mahasiswa FKIP Unusa cenderung memiliki sikap toleransi tinggi dan pada kondisi mana mahasiswa FKIP Unusa perlu mendapatkan perhatian dalam hal toleransi.

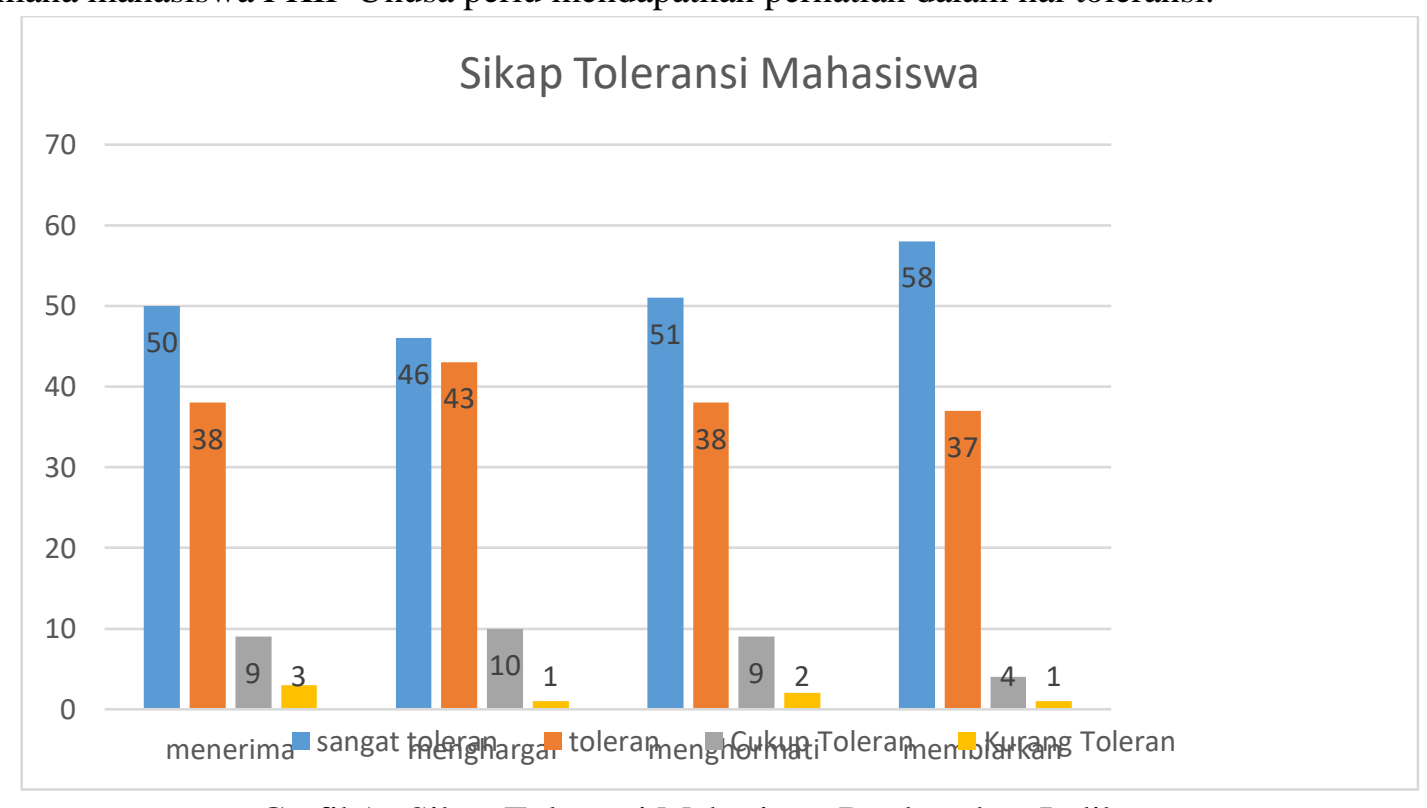

Grafik1 : Sikap Toleransi Mahasiswa Berdasarkan Indikator

Berdasarkan tabel di atas nampak bahwa sikap toleransi mahasiwa FKIP Unusa dari beberapa indikator. Pada indikator atau unsur membiarkan orang lain dan tidak memaksakan orang lain cenderung lebih tinggi dibandingkan unsur yang lain. Di susul menghormati orang lain dan menerima perbedaan. Keduanya samasama lebih dari 50\%. kemudian pada unsur menghargai orang lain antara sangat sering dan sering selisih $0,3 \%$ yakni antara $43 \%$ dan $46 \%$. Ini menunjukan bahwa sikap toleransi mahasiwa FKIP Unusa terhitung sangat baik. Jika dicermati dari kacamata intoleran, Nampak bahwa sangat sedikit bahkan kecil sekali yang mengindikasikan intoleran. Dari keempat unsur tersebut tidak ada unsur yang lebih dari 3\%. Menerima perbedaan 3\%, menghormati orang lain $2 \%$ dan sisanya menghargai orang lain dan membiarkan hanya $1 \%$. Angka yang sangat membanggakan bagi FKIP Unusa. Artinya kemungkinan untuk bersikap intoleran sangat rendah sekali. Meskipun demikian harus disadari dan diwaspadai untuk terus menggemakan sikap toleransi kepada mahasiwa khususnya mahasiswa FKIP Unusa.

Dalam kondisi menerima perbedaan, beberapa kondisi yang dilontarkan kepada responden antara lain: bagaimana responden berinteraksi dengan teman yang seagama saja; apakah responden akan berteman tanpa 
membeda bedakan; apakah mereka memotong pembicaraan orang; apakah responden memberikan kesempatan orang untuk mengkritik pendapatnya; serta apakah responden memaksakan keyakinan kepada orang lain. hasil yang diperoleh sangat menggembirakan karena mahasiwa FKIP Unusa dalam menghadapi kasus lebih mengedepankan menghargai perbedaan.

Seseorang akan dihargai apabila mampu menghargai orang lain. Kalimat inilah yang banyak kita jumpai dari beberapa percakapan sehari-hari. Kalimat tersebut menunjukan pentingnya sikap saling menghargai. Perbedaan adalah sebuah keniscayaan yang tidak dapat dihindari lagi. Kunci dari perbedaan itu adalah saling menghargai. Mahasiswa keguruan menunjukan angka yang cukup membanggakan dalam hal menghargai perbedaan. Bahkan angka yang menunjukan kurang toleran hanya satu persen. Kondisi ini sangat mendukung misi Unusa sebagai kampus Rahmatan lil Alamin. Indikator toleransi berikutnya adalah menghormati keyakinan orang lain. Setiap orang tentu memiliki keyakinan, pendapat serta gagasan tersendiri dalam menyikapi suatu hal. Adalah hal yang wajar dan manusiawi ketika hal ini berbeda. Penekananya adalah bagaimana individu mampu menghormati perbedaan tersebut sebagai suatu anugerah yang harus diterima. Orang yang toleran adalah orang yang mampu menekan apa yang tidak disukai namun memilih untuk tidak melakukannya (Dasli, 2016). Responden tentu bisa tidak menghargai keyakinan orang lain, menolak adanya pendirian tempat ibadah di tempat tinggalnya, namun mereka ampak jelas untuk tidak melakukannya. Inilah yang disebut sebagai wujud seseorang yang toleran.

Indikator sikap toleransi yang terkahir adalah membiarkan atau tidak memaksakan kehendak kepada orang lain. Toleransi harus dimulai dari hal-hal yang sederhana dan mudah untuk diimplementasikan. Masyarakat paham betul hal ini, namun banyak diantaranya yang tidak mewujudkan dalam sebuah tindakan. Namun hal berbeda ditunjukan oleh mahasiswa FKIP Unusa sebagai calon guru. Mereka menunjukan sikap toleransi dengan baik melalui membiarkan dan tidak memaksakan. Satu hal yang harus diperhatikan adalah penelitian ini merupakan penelitian tentang sikap bukan perilaku atau karakter. Artinya ada dua kemungkinan yang muncul. Pertama, ada kemungkinan antara karakter dan sikap yang diambil sejalan. Artinya apa yang disebutkan data di atas adalah cerminan dari karakter mahasiswa FKIP Unusa. Kemungkinan kedua, adalah bisa jadi ada perbedaan antara apa yang dijawab dengan perilaku atau karakternya. Responden mengisi yang baik-baik saja, meskipun berbeda dengan dirinya. Hasil tersebut apabila dipaparkan dalam bentuk sajian presentase dengan mengkonversi dari skala likert yang diberikan pada butir jawaban dengan skala toleransi nampak hasil yang sepadan. Jawaban sangat sering dikonversi menjadi sangat toleran; sering menjadi toleran; kadang-kadang menjadi cukup toleran dan tidak pernah menjadi kurang toleran. Maka hasil rangkumannya dapat dicermati pada grafik berikut.

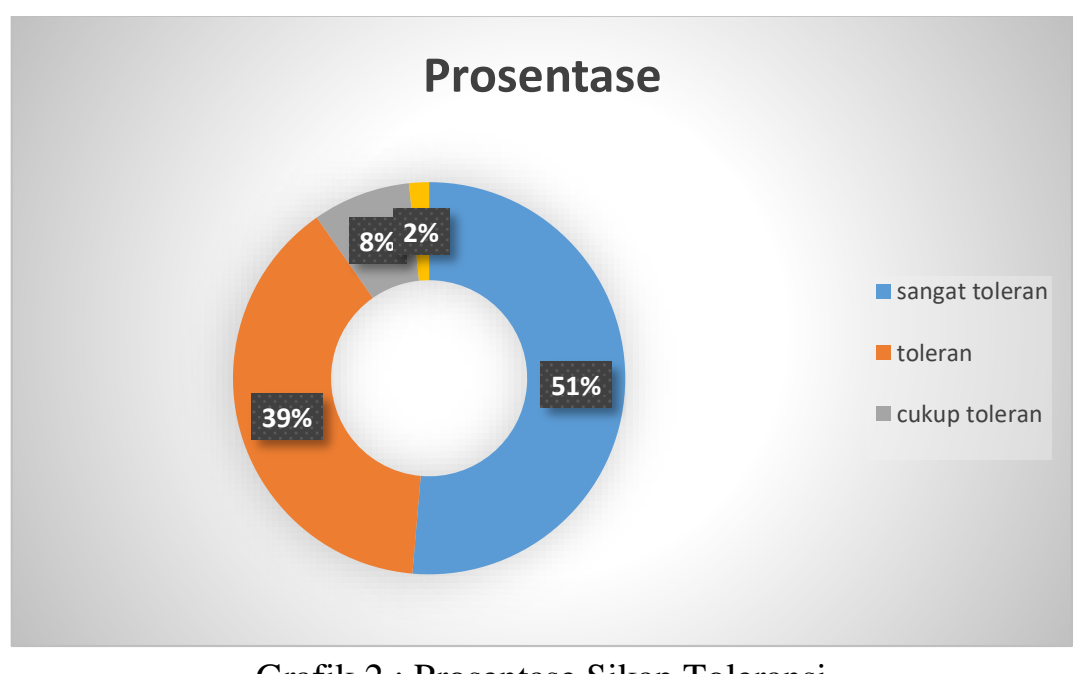

Grafik 2 : Prosentase Sikap Toleransi 
Grafik di atas menunjukan potret sikap toleransi mahasiswa FKIP Unusa yang sangat membanggakan. $51 \%$ mahasiswa FKIP Unusa sangat toleran, 39\% toleran dan $8 \%$ cukup toleran. Sisanya hanya $2 \%$ yang kurang toleran. Hasil ini seolah memberikan narasi bahwa calon guru yang dibina oleh Unusa merupakan calon guru yang dekat dengan nilai-nilai toleransi dan jauh dari nilai intoleran. Semangat mewujudkan mahasiswa sebagai garda toleransi dapa terwujud jika mahasiswanya seperti pada hasil penelitian ini.

Hasil penelitian ini dapat menjadi bahan kajian bersama dalam mengembangkan sikap toleransi. Sikap toleransi di kalangan mahasiswa keguruan di Unusa tidak memiliki masalah yang berarti. Berbeda dengan hasil penelitian yang dilakukan oleh (Mediaindonesia.com, 2020; Setara-institute.org, 2020). Hal ini dikarenakan subjek penelitian fokus pada mahasiswa FKIP Unusa. Penelitian toleransi terdahulu umumnya mengkaji kasus-kasus yang terjadi di masyarakat yang menunjukan sikap intoleransi. Kasus-kasus intoleran didata dan dihitung untuk dianalisis. Kasus-kasus tersebut kemudian dibandingkan dengan tahun-tahun sebelumnya. Hasil kajian dipaparkan dan menjadi bahan laporan dalam bentuk kuantitatif.

Penelitian ini berbeda dengan kedua penelitiaan di atas karena fokusnya adalah pada level mahasiswa dengan tidak menghitung jumlah perbandingan setiap tahun. Penelitian lebih fokus pada gambaran sikap toleransi yang ditunjukan mahasiswa berdasarkan indikator sikap toleransi. Hasil penelitian di atas juga tidak menggambarkan rangkaian kasus, melainkan memberikan gambaran terkait sikap yang direspon mahasiswa ketika berada pada sebuah kondisi tertentu.

Hasil temuan ini juga memberikan keterbatasan bahwa penelitian hanya berfokus pada mahasiswa FKIP di Unusa tidak mahasiswa di beberapa perguruan tinggi. Hal ini sesuai dengan misi Unusa yaitu dalam rangka menyiapkan generasi Rahmatan Lil Alamin. Unusa memberikan berbagai macam kegiatan dalam rangka menyiapkan generasi yang toleran sesuai dengan visi perguruan tinggi. Dengan demikian, penelitian ini tidak dapat digeneralisasi bahwa sikap toleransi pada jenjang mahasiswa berada level yang memuaskan. Latar belakang dan suana kampus tidak dapat disamakan. Bisa jadi antarperguruan tinggi memiliki nuansa dan kondisi yang berbeda-beda, terlebih subjek yang menjadi penelitian adalah Mahasiswa keguruan.

Temuan penelitian memberikan data bahwa sikap toleransi mahasiswa FKIP Unusa pada tataran yang memuaskan. Pepatah mengatakan mempertahankan lebih sulit daripada mendapatkan. Artinya dalam kondisi seperti ini, memupuk sikap toleransi menjadi syarat wajib agar mahasiswa memiliki sikap yang toleran dan mampu menjadi calon guru yang kemudian mampu menyebarkan nilai-nilai kebaikan di dalam masyarakat. Guru bukanlah sebagai profesi transfer pengetahuan, lebih dari itu guru juga mengajarkan sikap dan karakter muliah kepada peserta didik.

Mahasiswa FKIP Unusa memberikan sebuah harapan besar bagi terwujudkanya lingkungan yang toleran yang ramah dengan perbedaan yang mau menerima perbedaan dengan santun. Mampu menumbuhkan generasi yang mampu menghormati adanya perbedaan. Generasi-generasi yang tidak memaksakan keinginan dan membiarkan orang lain bertindak sesuai dengan keyakinan dan prinsipnya masing-masing. Dengan demikian kebhinnekaan di Indonesia akan menjadi Bhinneka yang tunggal ika. Perbedaan warna yang indah seperti pelangi.

\section{KESIMPULAN}

Sikap Toleransi mutlak dimiliki oleh setiap warga negara tanpa terkecuali. Mahasiswa memiliki peran penting untuk mempromosikan nilai toleransi. Mahasiswa keguruan perlu disiapkan untuk menanamkan pendidikan karakter dengan didahului memiliki karakter yang baik. Guru merupakan teladan bagi siswa. Potret sikap toleransi mahasiswa keguruan menunjukan sangat toleran. Mulai dari unsur menghargai, menerima, menghormati perbedaan sampai pada tidak memaksakan atau membiarkan orang lain melakukan sesuatu. Potret yang menggambarkan kegembiraan untuk agen pendidikan karakter. Meskipun demikian tetap perlu dipupuk dan dikembangkan. Sikap yang ditunjukan perlu diwujudkan dalam kehidupan sehari-hari 
DOI: https://doi.org/10.31004/edukatif.v3i3.455

sehingga menjadi karakter. Toleransi memiliki batasan, karena tidak semua tindakan dapat ditoleransi. Tindakan yang melanggar norma dan prinsip tidak boleh ditoleransi.

\section{DAFTAR PUSTAKA}

Akhwani, A. (2018). Pembelajaran PPKn dengan Value Clarification Technique Berbantuan Role Playing terhadap Keterampilan Intelektual Siswa SMA. Education and Human Development Journal, 3(2), 121129. https://doi.org/10.33086/ehdj.v3i2.50

Akhwani, A. (2019). Strategy of Digital Etiquette Education of Elementary School Students. PrimaryEdu Journal of Primary Education, 3(2), 43. https://doi.org/10.22460/pej.v3i2.1378

Akhwani, \& Nurizka, R. (2021). Meta-Analisis Quasi Eksperimental Model Pembelajaran Value Clarification Technique (VCT) Terhadap Terhadap Prestasi Belajar Siswa Sekolah Dasar. Jurnal Basicedu, 5(2), 446454. https://doi.org/https://doi.org/10.31004/basicedu.v5i2.706 Copyright

Amrin, S. (2021). Analisis Keterampilan Mengajar Mahasiswa Pendidikan Ekonomi Universitas Flores. EDUKATIF: Jurnal Ilmu Pendidikan, 3(1), 58-65.

Bahari, H. (2010). Toleransi beragama mahasiswa (Studi tentang Pengaruh Kepribadian, Keterlibatan Organisasi, Hasil Belajar Pendidikan Agama, dan Lingkungan Pendidikan terhadap Toleransi Mahasiswa Berbeda Agama pada 7 Perguruan Tinggi Umum Negeri). Badan Litbang dan Diklat Kementerian Agama.

Balint, P. (2016). The importance of racial tolerance for anti-racism. Ethnic and Racial Studies, 39(1), 16-32. https://doi.org/10.1080/01419870.2016.1099713

Balint, P. A. (2010). Toleration, Respect and Recognition in Education Educational Philosophy and Theory Special Issue Book Series. In M. Sardoc ` (Ed.), Toleration, Respect and Recognition in Education (hal. 123). Wiley-Blackweell.

Besch, T. M., \& Lee, J. S. (2017). On toleration in social work. European Journal of Social Work, 21(2), 311322. https://doi.org/10.1080/13691457.2017.1286460

Bukhori, B. (2021). Toleransi terhadap umat Kristiani ditinjau dari fundamentalisme agama dan kontrol diri. IAIN Walisongo Semarang.

Dasli, M. (2016). Intercultural education of tolerance and hospitality. Discourse, 38(5), 676-687. https://doi.org/10.1080/01596306.2015.1135308

Indonesia, R. (2005). Undang-Undang Republik Indonesia Nomor 14 Tahun 2005 tentang Guru dan Dosen. March, 25-27.

Jones, P. N. (2010). Toleration and recognition: What should we teach? Educational Philosophy and Theory, 42(1), 38-56. https://doi.org/10.1111/j.1469-5812.2008.00507.x

Kemdiknas. (2020). Pengembangan Pendidikan Budaya dan Karakter Bangsa, pedoman sekolah. Badan Penelitian dan Pengembangan Pusat Kurikulum.

Kusumawardani, F., Akhwani, \& Taufiq, N. M. (2021). Pendidikan Karakter Berbasis Nilai-nilai Pancasila melalui Keteladanan dan Pembiasaan di Sekolah Dasar. Jurnal Pancasila Dan Kewarganegaraan, 6(1), $1-10$.

Lægaard, S. (2010). Recognition and toleration: Conflicting approaches to diversity in education? Educational Philosophy and Theory, 42(1), 22-37. https://doi.org/10.1111/j.1469-5812.2008.00471.x

Lee, J. S., \& Besch, T. M. (2018). Critical reflection on toleration in social work. European Journal of Social Work, 23(1), 18-29. https://doi.org/10.1080/13691457.2018.1499612

Maulana, H. A. (2021). Persepsi Mahasiswa terhadap Pembelajaran Daring di Pendidikan Tinggi Vokasi : Studi Perbandingan antara Penggunaan Google Classroom dan Zoom Meeting. Edukatif: Jurnal Ilmu 
899 Potret Sikap Toleransi Mahasiswa Keguruan dalam Menyiapkan Generasi Rahmatan Lil Alamin - Akhwani, Moh Wahyu Kurniawan

DOI: https://doi.org/10.31004/edukatif.v3i3.455

Pendidikan, 3(1), 188-195.

Mediaindonesia.com. (2020). Survei Wahid Institute: Intoleransi-Radikalisme Cenderung Naik. Media Indonesia. https://mediaindonesia.com/politik-dan-hukum/284269/survei-wahid-institute-intoleransiradikalisme-cenderung-naik

Mucharomah, M. (2017). Guru di Era Milenial dalam Bingkai Rahmatan Lil Alamin. Edukasia Islamika, 2(2), 172. https://doi.org/10.28918/jei.v2i2.1667

Ramadhaniar, N., Akhwani, Hidayat, T., \& Taufiq, M. (2020). Harmoni Pengetahuan Dan Sikap Toleransi. BINA GOGIK, 7(2), 1-11.

Ruyter, D. J. de, \& Miedema, S. (2011). Moral Education and Development: A Lifetime Commitment. In Journal of Chemical Information and Modeling (Vol. 53, Nomor 9).

Schirmer, W., Weidenstedt, L., \& Reich, W. (2012). From Tolerance to Respect in Inter-Ethnic Contexts. Journal of Ethnic and Migration Studies, 38(7), 1049-1065. https://doi.org/10.1080/1369183X.2012.681448

Setara-institute.org. (2020). Terjadi Penjalaran Intoleransi di daerah, Pemerintah Pusat Harus Hadir. SETARA Institute. https://setara-institute.org/terjadi-penjalaran-intoleransi-di-daerah-pemerintah-pusatharus-hadir/

Starkey, H., \& Osler, A. (2006). Education for Democratic Citizenship: a review of research, policy and practice 1995-2005. Research Papers in Education, 21(4), 433-466. http://dx.doi.org/10.1080/02671520600942438

Supriyanto, W., \& Iswandari, R. (2017). Kecenderungan Sivitas Akademika dalam Memilih Sumber Referensi untuk Penyusunan Karya Tulis Ilmiah di Perguruan Tinggi. Berkala Ilmu Perpustakaan dan Informasi, 13(1), 79. https://doi.org/10.22146/bip.26074

Suriadi, H. J., Firman, F., \& Ahmad, R. (2021). Analisis Problema Pembelajaran Daring Terhadap Pendidikan Karakter Peserta Didik. Edukatif: Jurnal Ilmu Pendidikan, 3(1), 165-173.

Undang-undang 20. (2003). Sistem Pendidikan Nasional.

UNESCO. (1994). Tolerance: the threshold of peace A teaching / learning guide for education for peace, human rights and democracy. UNESCO.

UNESCO. (1996). The Declaration of Principles on Tolerance. In Diogenes. https://doi.org/10.1177/039219219604417623 